\title{
Revitalizing Small-Scale Agriculture: Rental Policies of Alienated State Lands of Sri Lanka
}

\author{
D. Marawila*
}

\begin{abstract}
Currently, the small-scale farmers in Sri Lanka are loosing competitiveness and rapidly moving out of agriculture, lack of access as well as well defined rights to land being major limitations. Possibility of increasing agriculture production through improved land rental markets in the alienated state lands was conversed in this study and results revealed that the removal of restrictions is likely to facilitate smooth functioning of rental market and thereby improve the land use efficiency. The study concluded that provided a conducive economic environment, land rental market can be used as an effective tool in the rural development process of the country.
\end{abstract}

\section{Introduction}

In Sri Lanka, in spite of the expanding industrial and service sectors, agriculture sector still plays a prominent role in terms of food security, employment, income generation, and foreign exchange earnings. Sri Lankan agriculture is dualistic in character, one sector being domestically oriented with paddy as the main crop and the other more commercially oriented plantation sector which principally consists of tea, rubber and coconut. The former produces paddy, subsidiary food crops, fruits and vegetables predominantly in small holdings while the latter produces tea, rubber and coconut in small/medium to large scale estates. At present agricultural lands cover 30\% (2.26 million ha) of the total land area (World Bank, 2001) of the country and nearly $40 \%$ the agricultural holdings are small holdings (Census of Agriculture, 2002). Agricultural sector provides employment to nearly 33\% of the national labour force and livelihood to nearly $50 \%$ of the poor in the country (Sri Lanka Integrated Survey, 1999-2000). Agriculture is practiced under both rainfed and irrigated conditions mainly depending on the seasonality of the rainfall in dry zone areas while wet zone agriculture is predominantly rainfed. Irrigated agriculture contributes approximately to $6 \%$ of annual GDP of Sri Lanka and covers an extent of 0.66 million ha or $29 \%$ of the farm area. The Area is serviced by irrigation infrastructure that comprises 60 large multi-purpose dams, 260 large to medium sized major irrigation schemes and 12,000 minor working village tanks (Census of Agriculture,

Research Officer, Institute of Policy Studies, Sri Lanka. 
2002). About $85 \%$ of the water supply derived from above sources is used for water intensive irrigated paddy agriculture (Wanigaratne, 2006). It provides employment for more than 0.7 million farm families (approximately 2.2 million people). Majority of the small-scale operators are subsistence farmers with low capacity and resource endowment while commercial agriculture is practiced by handful of producers.

Colonization/settlement programmes initiated in 1930's with provisions for irrigated agriculture is the landmark in the land policies as well as in dry zone development of Sri Lanka and over 2 million land holdings have been alienated under different land distribution programmes under different tenure schemes by the mid of 2000 . The policies and regulation related to alienated lands have not been revised since the inception apparently leading to number of conflicts related to land transfers, inheritance and use. About 1.38 million ha of agricultural lands $(63 \%$ of the total agricultural lands) are owned by the state, managed under various forms of state established and guided settlement projects $(575,449 \mathrm{ha})$ and as regularized encroachments (260,283 ha) being occupied and farmed by the families who had received land under lease and grant permits (Wanigaratne, 2006).

Even though no legal provisions are made for upright sales or rental transfers in alienated state lands, it is apparent that they are taking place in considerable numbers in almost all the settlements. There are arguments pro and against conferring land transfer rights to the alienated state land owners and one of the major arguments is that free ownership rights would make the poor farmers poorer (Fernando, 2004). However, such arguments are not supported by profound theoretical analysis of the situation. This study is an attempt to explore the behaviour of the land rental market in the smallholding sector in the alienated state lands of Sri Lanka. The study basically tests two hypotheses; whether (1) liberalization of the land rental markets is likely to have positive impacts on the livelihoods of the allotees and (2) less access to land is likely to move people involved in irrigated agriculture, from farming to off farm employments. The study identifies the socio-economic characteristics of households that influence the decision to participate in the land rental market and of the contract choices. Further, the above hypothesises would be tested by analysing the impact of the rental market on the socioeconomic status of the tenants involved in such contracts, particularly on the income and the asset endowment of the tenants. 


\section{Background}

\section{Overview of Land Policies}

Modern land policies of Sri Lanka date back from the Land Development Ordinance (LDO) of 1935 which set the future course of land development of Sri Lanka (Goonewardene and Hatten, 1990; Madduma Bandara, 1990) and transferred crown lands for purpose of cultivation to near landless or landless peasants. By the early twentieth century the focus of agricultural development shifted from the wet zone to dry zone since there were no lands for expansion of cultivation in the wet zone. Lack of water supply was one of the major problems in the dry zone and after introducing irrigation systems large extent of lands was put under permanent cultivation and peasants from wet zone were resettled in the irrigated areas. Galoya settlement programme which was implemented in the 1930's was the first land alienation programme and since then number of programmes (Table 2.1) were implemented. The LDO introduced to safeguard the peasantry were subjected to series of conditions including restrictions on inheritance, subdivision and transfers (Dharmaratne et al., 2006) while these lands can only be accepted as collateral for mortgage by co-operative societies (Gamage, 2000). Land distribution and colonisation programmes introduced after independence in 1948 were mainly targeted at providing welfare to the allottees. Hence, subsidy schemes for agricultural inputs, a minimum wage mechanism and a progressive tax system was designed to transfer surplus, towards building the necessary socio-economic infrastructure (Alailima, 2001). The pace of this programme was further quickened by the Accelerated Mahaweli programme implemented in late 70's onwards.

The land ownership legislation introduced in the 1970's was influenced by socialist ideas and led the nationalisation of assets owned by private companies and large land holdings which were over 50 acres. (Balassuriya and Maude, 1991). Lands which were taken from the Land Reform Commission (1970 and 1977) were vested in the Land Commissioner's Department for distribution. Approximately 981,160 acres of land have been acquired under the Land Reform Commissions and of them about $10 \%$ has been granted to the low income groups officially under the Land Grant (Special) Provisions Act. This act was introduced with similar objectives as the LDO in 1979 to provide land to the 'landless' and by the year 2004, 75,177 grants had been issued under the Land Grant (Special) Provisions Act (Dharmaratne et al., 2006). According to Alwis and Wanigaratne (2006), under this programme, small blocks of 0.25 acre to 1 acre were distributed among the landless, nevertheless, the distribution of small parcels of land to a large number proved counter-productive over the years. 
Table 2.1: $\quad$ Land distributed under the Land Development Ordinance by 2003

\begin{tabular}{lcrrr}
\hline Programme & $\begin{array}{c}\text { No. of } \\
\text { allotments }\end{array}$ & \% & $\begin{array}{c}\text { Land (ha) } \\
\text { distributed }\end{array}$ & \multicolumn{1}{c}{$\%$} \\
\hline Highland settlement & 9,959 & 0.83 & 15,023 & 1.80 \\
Major settlement & 100,117 & 8.34 & 168,835 & 20.20 \\
Village expansion & 515,078 & 42.91 & 301,468 & 36.07 \\
Middle class & 13,385 & 1.11 & 63,265 & 7.57 \\
Youth settlement & 6,245 & 0.52 & 7,881 & 0.94 \\
Land grant & 63,574 & 5.30 & 18,977 & 2.27 \\
Regularization of & 492,143 & 40.99 & 260,283 & 31.14 \\
encroachments & & & & \\
\hline Total & $1,200,501$ & & 835,732 & \\
\hline
\end{tabular}

Source: Land Commissioner's Department (2003)

Since 1935, 1.2 million LDO permits have been issued including over 70,000 permits by the Mahaweli Authority and about $80 \%$ of that has been converted to grants. The largest number of permits (just over 500,000 permits) has been for village expansion. Regularization of encroachment is the second largest category and the only permit category for which permits are still being issued. Of the 1.2 million LDO permits, about 1 million have been converted to LDO grants, leaving 200,000 still as permits. In addition about 80,000 grants have been issued under the LG (SP) since 1979 but this has stopped after 1980's.

Issuing grants for the lands alienated under LDO commenced in 1982 and land grants were variously titled as Swarnabhoomi ${ }^{2}(1982-1994)$, Jayabhoomi $^{3}$ (1995-2002), Isurubhoomi (2002-2004) and back to Jayabhoomi in 2004-2005 (Wanigaratne, 2006). By the end of 2004, 318,038 Swarnabhoomi and 676,266 Jayabhoomi grants have been issued by the Land Commissioner's Department while 45,166 Jayabhoomi grants were issued under the Mahaweli Authority. Land grant title was introduced in 1994 and was applied to both Land Development Ordinance based irrigated settlements as well as land alienated under Land reforms laws of 1972 and 1975.

Successive governments up to 1977 had policies of protecting their small-scale agriculture and provided them with various support schemes to be kept them in their livelihoods while market oriented policies pushed by

Swarnabhoomi grants are prepared with a Survey map.

3 Jayaboomi grants are prepared without a Survey map.

Grant is a permanent document which confers tenure close to that of a freehold title subject to several conditions that transfers require prior permission, prohibition of fragmentation and sub-division, inheritance restrictions, etc. 
different parties since 1977 (Fernando, 2006). Restrictions on land ownership and mortgaging were eased in the 1980s and grantees were able to mortgage their holdings with state lending agencies, which helped them in obtaining loans for investment (Rathnayake, 2002).

Registration of Title Act No. 21 of 1998 was enacted with the objective of providing titles to land parcels. The Land Ownership Bill was suggested by the World Bank to give freehold titles to the allottees of the alienated state lands and this led to much controversy as some were of the view that it would create more negative impacts on the poor. Fernando (2004) argues that this proposed reform would have resulted in large numbers of the rural agricultural population in Sri Lanka deprived of their agricultural livelihoods. However, Land Commissioner's Department of Sri Lanka has already taken initiatives to issue freehold titles to highlands particularly lands alienated under village expansion schemes which cover the largest proportion of the distributed lands.

\section{Tenure Reforms}

Burgeoning population over the past few decades in the country has exerted much pressure on the agricultural lands thus resulting in severe fragmentation, landlessness as well as complex tenure arrangements. Lands in the wet zone are severely affected compared to the dry zone due to population pressure as well as lands being privately owned. Commonly practiced forms of tenancy are Ande ${ }^{4}$, Thattumaru ${ }^{5}$ and Kattimaru. ${ }^{6}$ Popular belief was that the tenants are being exploited by the landlords and therefore the productivity and the adoption of new technology both are hampered. Hence, a number of policies were institutionalized to safeguard and to secure rights of the tenant cultivators by successive governments.

The government enacted two tenure reforms, Paddy Lands Acts of 1953 and 1958 with the objective of ensuring tenure security and regulating the rental payments. Even though these were implemented with the purpose of increasing productivity through increased tenure security they turned out to be more detrimental than beneficial to the landlord-tenant relationship leading

4 Tenant cultivator is responsible for all the work and gets a share of the crop for his efforts while landlord is virtually an absentee landlord exercising little supervision over the cultivation.

5 Form of rotational cultivation whereby the ownership of a particular land is taken in turn to prevent the physical subdivision of a unit of land so as to maintain an economic unit of cultivation.

6 Sub-divided plots of a land are cultivated rotationally by the co-owners/joint owners and all owners occupy some portion of the land simultaneously. 
ultimately to the eviction of a large number of tenants. Between 1958 and 1972 about 43,000 tenants were reported to have been evicted and only $18 \%$ of them ended in a final restoration (Gamage, 2000). Agrarian Services Act of 1979 also aimed at securing tenure rights of tenant cultivators of paddy and improving the productivity of such lands and was considered as a more realistic approach in solving the problem of the paddy sector. Agrarian Development Act No. 46 of 2000 was aimed at ensuring maximum utilization of agricultural land by imposing restrictions on conversion of agricultural land into non-agricultural uses.

Even though a number of policies were brought to effect from time to time by successive governments on the use and distribution of land, absence of a suitable institutional framework to execute the provisions available under legislation has been a major limitation. Lack of coordination among the agencies with overlapping mandates, lack of transparency, lack of technical expertise to handle the issues efficiently, lack of accessibility, high transaction costs and inadequate public awareness are the major deficiencies of the present administrative system (Institute of Policy Studies, 2004).

\section{Agricultural Small-Holding Sector of Sri Lanka}

Appreciable social development achieved by Sri Lanka during the post independence era could reasonably be said to be as a result of successive government policies that attempted to protect and strengthen small farmer based agriculture and to protect social welfare (Fernando, 2004). However, over the last two decades it became a less attractive income source leading to the movement of large number of farmers out of agriculture seeking non farm opportunities. The average size of a small-holding in Sri Lanka declined by 64\% over the last 56 years, from 1.3 ha in 1946 to 0.47 ha by 2002 (Census of Agriculture, 2002) largely owing to the growing population and lack of a continued programme to accommodate the increasing numbers.

About $92 \%$ of the agricultural land area within the major and minor schemes and rain-fed areas are small-holdings below 2 ha. They are found distributed over 3.5 million distinct land parcels held by about 3.6 million rural households under a wide range of tenure forms and transactional relationships (Gamage, 2000). As of 2001, approximately 1.2 million land operators had been given over 2.5 million acres of land under permits, hence over $70 \%$ of Sri Lanka's small-holder farmers operate under the LDO system and over $65 \%$ of the land cultivated by small-holders is covered within the LDO (Dharmaratne et al., 2006). A study by World Bank (1996) highlighted that land and labour market as the major determinants of the farmer's behaviour. Amongst the macro and micro environmental factors that have led to a stagnant small-holding sector, size of the land holdings, land productivity 
and status of land tenure are found prominent and have contributed much to the low income and thereby persistent agrarian poverty.

\section{Land Rental Market}

There is substantial amount of empirical evidence showing the possible positive implications of rental markets on the poor farmers. Silva (2000) has emphasized that the ladder hypothesis ${ }^{7}$ has important policy implications that are especially relevant to countries like Sri Lanka and in the case of share-cropping, it provides a vital link by which unskilled tenants acquire necessary management skills in partnerships with landlords. Deninger et al., (2003) indicate that rentals transfer land from households with low agricultural ability and relatively abundant land endowments to those with high agricultural ability and scarce endowments. By the study on rural India, Mearns (1999) concluded that given the rigidities in the land sale market, the lease market plays an important role in matching land, labour and capital endowment and an important means by which the poor gain access to land. It is argued that decentralised land rental market may contribute more to equity and efficiency goals having advantages over administrative reallocation (Deninger and Jin, 2005). The World Bank (1999) has found that government induced restrictions on the functioning of land rental markets in developing countries have become a major source of inefficiency. Deninger et al., (2003). Removing obstacles, government regulations or imperfections in the markets preventing the smooth functioning of land rental markets and taking measures that enhance potential tenants endowment and bargaining power can considerably increase both the welfare of the poor and overall efficiency of resource allocation (Deninger and Feder, 2001).

The welfare impact of rental contract depends basically on the terms of contract and it has been long pointed out that rental arrangements based on fixed terms are more likely to maximize productivity (Deninger, 2003) than share-cropping contracts, which are the second best solution. Deninger and Feder (2001) have shown that any contract other than fixed rent would result in undersupply of the effort by the producer and this would lower the total production. The nature of rental contracts seems to be highly biased to a specific locality. Tenants participating in the share tenancy and fixed rental contracts in rural areas of Sri Lanka also appear to come from two different

7 Agricultural ladder hypothesis implies that farmers climb a "ladder" from agricultural labourer to share tenants and then to fixed tenancy through gradual acquisition of skills and finally make the transition to land ownership at a latter stage. (Silva, 2000; Deninger, 2003). 
classes $^{8}$ of people; their concerns on the contract choice may thus be different (Marawila and Samaratunga, 2006)

Abide by the regulations set by the LDO, lands alienated under the ordinance are legally under the control and custody of the Divisional Secretary or Provisional Land Commissioners and the transactions, both sales and rental, are prohibited. However, previous studies (Dharmaratne et al., 2006; Samaratunga and Marawila, 2006), have confirmed that all forms of transactions take place in the alienated state lands. It was also noticed that in certain occasions contracting parties arrive at unfavourable terms of contracts since the transactions take place informally.

Table 2.3: $\quad$ Paddy: By size class and operational status

\begin{tabular}{lccc}
\hline Size class (acres) & Owner operated land & Tenant operated land & Total \\
\hline$<1 / 4$ & 32,851 & 6,460 & 39,311 \\
$1 / 4-<1 / 2$ & 97,691 & 31,952 & 129,643 \\
$1 / 2-<1$ & 165,350 & 75,641 & 240,991 \\
$1-<2$ & 161,095 & 75,642 & 236,737 \\
$2-<5$ & 180,447 & 45,592 & 226,039 \\
5 and above & 19,156 & 5,128 & 24,284 \\
\hline Total & 656,590 & 240,415 & 897,005 \\
\hline
\end{tabular}

Source: Census of Agriculture, 2002

\section{Methodology}

\section{The Empirical Model}

This study focuses on the rental behaviour of both tenants and landlords and estimates the determinants of the rental market participation of the two agents, in terms of the contract choices. The regressands are qualitative and categorical variables with two possible outcomes or probability of the event lying between 0 and 1 , hence a binary logit model which guarantees the conditional probability between the logical limits of 0 and 1 was used in the estimation. Sequential binomial logit equations were used for the different contract choices and the parameters were estimated using the maximum likelihood method. Possible determinants identified in the field survey were used as the explanatory variables in the model.

8 In general more resource endowed, skilled tenants are involved in fixed rental contracts while the tenants who lack resources as well as entrepreneurial skills are involved in the share tenancy contracts. 


\section{Standard binomial logit model}

In logit model one hypothesizes that the probability of the occurance of the event is determined by the function

$$
P i=F\left(Z_{i}\right)=\frac{1}{1+e^{-Z i}}
$$

where, $\mathrm{Z}_{\mathrm{i}}=+\beta_{i}+\sum_{j=2}^{k} \beta_{j} \chi_{j i}+U_{i}$

When cumulative distribution of $\mathrm{U}_{\mathrm{i}}$ is logistic, then the $\mathrm{P}_{\mathrm{i}}$ take the form of the logit distribution and the logit model can be written as

$$
L_{i}=\ln \left(P_{i} / 1-P_{i}\right)=\beta_{1}+\beta_{2} X_{i}+\ldots \ldots \ldots \beta_{n} X_{m}+U_{i}
$$

where,

$L_{\mathrm{i}}=\operatorname{logit}$ or $\log$ of the odds ratio, which is liner in explanatory variables $\left(\mathrm{X}_{\mathrm{i}}\right)$ as well as in parameters

$P i$ ranges form zero and one, $\mathrm{P}_{\mathrm{i}}=1, \mathrm{~L}_{\mathrm{i}}=\ln (1 / 0)$

$\mathrm{P}_{\mathrm{i}}=0, \mathrm{~L}_{\mathrm{i}}=\ln (0 / 1)$

$\mathrm{X}_{\mathrm{i} \ldots \ldots . . . . \mathrm{X}_{\mathrm{m}}=\text { explanatory variables }}$

$\beta_{1 \ldots \ldots . . .} \beta_{\mathrm{n}}=$ parameters

$\mathrm{U}_{\mathrm{i}}=$ Stochastic error function,

The probability of occurrence of the event is determined by the

$$
P i=F(Z i)=\frac{1}{1+e^{-z i}}
$$

Explanatory variables were selected using the forward stepwise method and the statistical significance of the coefficients was measured using likelihood ratio (LR) statistics. Given the null hypothesis LR statistics follow the Chi square $\left(\mathrm{X}^{2}\right)$ distribution with degree of freedom equalling the number of explanatory variables (at $\alpha=0.05,0.01$ and 0.1 levels).

All the attributes which were likely to affect the rental behaviour of both tenants and landlords were employed as explanatory variables in the empirical models. These attributes were identified through an extensive literature survey as well as from the field survey as shown in Table 3.1 
Table 3.1: Explanatory variables used in determining the rented in/out behaviour of the tenants/landlords

\begin{tabular}{|c|c|c|}
\hline Rented in & Rented out & Description \\
\hline $\begin{array}{l}\text { Monthly income from } \\
\text { agriculture } \\
\text { Involvement in off-farm } \\
\text { employment }\end{array}$ & $\begin{array}{l}\text { Monthly income from } \\
\text { agriculture }\end{array}$ & $\begin{array}{l}\text { Current income from all the } \\
\text { agricultural activities } \\
\text { Whether any member of the } \\
\text { household is employed in off farm } \\
\text { employment or not }\end{array}$ \\
\hline $\begin{array}{l}\text { Extent of land having } \\
\text { ownership rights }\end{array}$ & $\begin{array}{l}\text { Extent of land having } \\
\text { ownership rights }\end{array}$ & $\begin{array}{l}\text { Extent of land to which any of the } \\
\text { household have full ownership rights }\end{array}$ \\
\hline Asset endowment & Asset endowment & $\begin{array}{l}\text { Value of the total assets the } \\
\text { household own in Rs. }\end{array}$ \\
\hline Share of the tenant & & $\begin{array}{l}\text { Share of crop that the tenants receive } \\
\text { as a percentage. }\end{array}$ \\
\hline With encroached land & $\begin{array}{l}\text { Having encroached } \\
\text { land }\end{array}$ & $\begin{array}{l}\text { Whether the household has } \\
\text { encroached land or not }\end{array}$ \\
\hline & $\begin{array}{l}\text { Income from non-farm } \\
\text { employment }\end{array}$ & $\begin{array}{l}\text { Household income from non -farm } \\
\text { employment activities }\end{array}$ \\
\hline Access to credit & & $\begin{array}{l}\text { Access of household to } \\
\text { formal/informal credit }\end{array}$ \\
\hline
\end{tabular}

In the case of analysing the impact of rental market on household income and the asset endowment two multiple linear regression models were fitted. Household total income (both farm and off farm income) and the value of assets (both land and other assets) were considered as dependent variables in each model and the rented extent with other likely determinants of income and asset endowment of household were used as the independent variables in order to obtain the best fitted model (Table 3.2).

Table 3.2: Dependent and independent variables of the multiple linear regression models

\begin{tabular}{ll}
\hline \multicolumn{1}{c}{ Model I: Income as a Regressor } & \multicolumn{1}{c}{$\begin{array}{c}\text { Model II: Asset Ownership as a } \\
\text { Regressor }\end{array}$} \\
\hline Land extent with full ownership rights & Land extent with full ownership rights \\
Rented extent & Rented extent \\
Enclosing an encroached land & Enclosing an encroached land \\
Asset endowment & Off farm income of household \\
& Agricultural Income of household \\
\hline
\end{tabular}




\section{Linear regression model}

$$
Y=\beta_{0}+\beta_{1} X_{1}+\beta_{2} X_{2}+\ldots \beta_{n} X_{n}+\mu
$$

Where,

$$
\begin{aligned}
& Y=\text { Dependent variable } \\
& X_{i} \ldots \ldots X_{n}=\text { explanatory variables } \\
& \beta_{0 \ldots \ldots \ldots . . .} \beta_{n}=\text { Coefficients } \\
& \mu=\text { Stochastic error }
\end{aligned}
$$

\section{Data Collection}

The study is based on both primary and secondary data. The empirical analysis is based on a household survey conducted by the Institute of Policy Studies of Sri Lanka in 2005, but the study has benefited by number of studies done on land market and land reforms by the institute Poverty and Social Impact Analysis (PSIA) of Sri Lanka's Land Reform (Dharmaratne et al., 2006, Rural Land Sector of Sri Lanka (Samaratunge and Marawila, 2006). The household survey was conducted in eight villages covering areas under land settlement programmes. To obtain a representative sample as possible, villages representing different land settlement (major and minor settlements, different cropping patterns) schemes were selected. Grama Niladhari's household list was considered as the sampling frame and 50 households were selected from each village to form the sample of 400 . Data were collected using a semi structured questionnaire from the households and key informant interviews. Secondary data were collected from the local officials including District Secretariat, Divisional secretariats, Grama Niladhari, Irrigation offices etc.

\section{Results and Discussion}

\section{Descriptive Statistics}

In the eight districts considered, people have benefited from a number of land settlement programmes and they include major settlements (Gal Oya and Mahaweli development projects), village expansions and regularization of encroachments by Land Commissioner's Department (LCD) as well as Mahaweli development Authority. These lands are operated under different tenurial status such as LDO permits by Mahaweli, LDO permits by LCD, land grants by LDO (Swarnabhoomi, Jayabhoomi and Isurubhoomi) and State Land Ordinance. Paddy was the major crop grown in these lands, however, a variety of crops (Other field crops, vegetables, fruits and plantation crops such as coconut) could be observed depending on the locality and the land 
distribution programme. Majority of the lands were operated by the owners and a substantial area of land was operated by tenants. The percentage of allottees involved in rental transactions by contract choice, in each district is shown in the Table 4.1.

Table 4.1: $\quad$ Rental market participation of allottees by district (\%)

\begin{tabular}{lrrrrrr}
\hline District & $\begin{array}{c}\text { Shared } \\
\text { in }\end{array}$ & $\begin{array}{c}\text { Leased } \\
\text { in }\end{array}$ & $\begin{array}{c}\text { Rented } \\
\text { in }\end{array}$ & $\begin{array}{c}\text { Shared } \\
\text { out }\end{array}$ & $\begin{array}{c}\text { Leased } \\
\text { out }\end{array}$ & $\begin{array}{c}\text { Rented } \\
\text { out }\end{array}$ \\
\hline Ampara & 6 & 23 & 29 & 2 & 16 & 18 \\
Kurunegala & 29 & 0 & 29 & 18 & 4 & 22 \\
Anuradhapura & 9 & 7 & 13 & 15 & 0 & 15 \\
Polonnaruwa & 30 & 5 & 35 & 15 & 2 & 17 \\
\hline Total & 14 & 6 & 20 & 11 & 5 & 16 \\
\hline
\end{tabular}

It shows that nearly $40 \%$ of the households are engaged in rental contracts and majority of the tenants as well as landlords are engaged in share contracts. Highest percentage of share contracts is reported in Kurunegala while Ampara reports the highest percentage of lease arrangements.

Average size of the holdings with titles, varies with the locality and depending on the tenure status of the land owner (Table 4.2). Average size of the holdings of the landlord's (households who have rented out land) is comparatively high to that of the tenants (households who have rented in lands) and the higher mean value in Ampara and Polonnaruwa are mainly due to few exceptional cases. In Anuradhapura and Polonnaruwa some tenants didn't have ownership to a single plot of land and were totally depending on the landlords for lands.

Table 4.2: $\quad$ Average size of holdings by tenure status

\begin{tabular}{lcccccc}
\hline District & \multicolumn{3}{c}{ Landlords } & \multicolumn{3}{c}{ Tenants } \\
& Minimum & Mean & Maximum & Minimum & Mean & Maximum \\
\hline Ampara & 1.5 & 3.8 & 5.0 & 1.5 & 6.1 & 26.5 \\
Kurunegala & 1.0 & 3.8 & 7.0 & 0.5 & 2.5 & 6.25 \\
Anuradhapura & 1.5 & 2.9 & 3.0 & 0.0 & 1.4 & 5.5 \\
Polonnaruwa & 0.25 & 1.5 & 4.0 & 0.0 & 2.8 & 10.0 \\
\hline
\end{tabular}

In general landlord's rental behaviour is believed to be affected by their involvement in off farm employment. An accepted principal in rental transactions is that the inefficient farmers move out of agriculture transferring their lands to more productive farmers. Also landlords having larger extents of land to which they had titles or claims are more likely to rent out lands. Table 4.3 shows the percentage of landlords who are engaged in off farm employments, who have claims on other lands, other than the allotments and who have encroached lands, in each district. It shows that more than $80 \%$ of 
the landlords in all the studied districts are involved in off farm employments implying that off-farm income is a major source of income.

Table 4.3: Common factors affecting the rental behaviour of landlords $(\%)$

\begin{tabular}{lccc}
\hline District & $\begin{array}{c}\text { Off farm } \\
\text { employment }\end{array}$ & $\begin{array}{c}\text { Households who } \\
\text { have claims on } \\
\text { other lands }\end{array}$ & $\begin{array}{c}\text { Households } \\
\text { who have } \\
\text { encroached } \\
\text { lands }\end{array}$ \\
\hline Ampara & 100 & 12 & 0 \\
Kurunegala & 100 & 33 & 50 \\
Anuradhapura & 84 & 0 & 0 \\
Polonnaruwa & 90 & 0 & 20 \\
\hline
\end{tabular}

Similarly rental behaviour of tenants is also assumed to be affected by their income from other sources and their involvement in off farm employments. The extent of the holdings under their control is also an important aspect, hence, the lands to which they don't have proper ownership rights but have claims and encroached are likely to determine their rental behaviour. Table 4.4 shows the tenant's involvement in off farm employments, whether they have claims on other lands and encroached lands, in each district.

Table 4.4: $\quad$ Common factors affecting the rental behaviour of tenants (\%)

\begin{tabular}{lccc}
\hline District & $\begin{array}{c}\text { Off farm } \\
\text { employment }\end{array}$ & $\begin{array}{c}\text { Households who } \\
\text { have claims on } \\
\text { other lands }\end{array}$ & $\begin{array}{c}\text { Households who } \\
\text { have } \\
\text { encroached } \\
\text { lands }\end{array}$ \\
\hline Ampara & 93 & 27 & 27 \\
Kurunegala & 100 & 25 & 13 \\
Anuradhapura & 45 & 31 & 62 \\
Polonnaruwa & 64 & 23 & 63 \\
\hline
\end{tabular}

Landlords' involvement in off-farm employment was higher than the tenants in all the districts except in Kurunegala. Most of the tenants had control of lands to which they did not have a clear title and majority of these lands were under cultivation. In particular, in Anuradhapura and Polonnaruwa, large extents of state lands were being encroached and not regularized. However, majority of the farmers in the study sample were cultivating successfully in these lands mostly during the Maha season and were also generating a considerable level of income out of them. 


\section{Empirical Results}

\section{Determinants of renting in land}

All the observed attributes (listed in the Table 3.1) of renting in behaviour, during the field survey, were employed in the logit estimation. However, few variables showed significant relationships with the dependent variables while the signs of many variables were in line with the theoretical expectations. Table 4.5 shows those significant determinants of household renting behaviour with respect to the two rental contract choices, share and leasing in. Monthly income from agriculture showed a significant positive relationship with the renting behaviour of those tenants who were having lease contracts while in the case of share contracts it was not significant. It implies that households who generate a considerable income out of agriculture show higher tendency to lease in.

In contrary to the general theory, involvement in off-farm employment showed a significant positive relationship with the renting in behaviour, in the case of both choices implying that more the involvement in off farm employment the more will be the engagement in rental market. This may be true with the lease tenants since they mostly grow at commercial level and need more capital for operations. Taking into consideration the current scenario of low income generated from agriculture and the trend towards migration from farming to off farm sector, this can also be true for the share farmers. Asset endowment also show a positive relationship with the choice of sharing in contrary to the theory implying larger the asset ownership tendency to share in will be high. In the state lands, apparently the tenants involved in sharing contracts were not of the poorest category and this may have led to the positive relationship with the asset endowment. General acceptance is tendency to share in reduces with the asset endowment but to increase with lease arrangements.

Extent of land with full ownership rights showed a significant negative relationship with the renting in behaviour of the share tenants and was insignificant for the lease holders. Mostly household tend to share in when they do not own lands but this may be different in leasing since they enter into long term contracts even when they have their own lands. Increase in the share, the tenant receives, shows a positive tendency with share in contracts in accordance with the theory. As a tenant receives a higher share, he is more willingly to involve in share contracts. 
37

Table 4.5: $\quad$ Determinants of rented land in- Binomial logit estimates

\begin{tabular}{llrlc}
\hline & \multicolumn{2}{c}{ Shared in } & \multicolumn{2}{c}{ Leased in } \\
& Coefficient & Std. Error & Coefficient & Std. Error \\
\hline $\begin{array}{l}\text { Constant } \\
\text { Monthly income }\end{array}$ & -4.0895 & 0.8483 & -3.7192 & 0.4801 \\
from agriculture & & & $0.0003 * * *$ & 0.00008 \\
$\begin{array}{l}\text { Involvement in off- } \\
\text { farm employment }\end{array}$ & $3.8223^{* * *}$ & 0.8248 & $1.5222^{* * *}$ & 0.6614 \\
$\begin{array}{l}\text { Extent of land with } \\
\text { ownership rights }\end{array}$ & $-0.7551^{* *}$ & 0.3017 & & \\
$\begin{array}{l}\text { Share of the tenant } \\
\text { Asset endowment }\end{array}$ & $0.0609 * * *$ & 0.0133 & & \\
$\begin{array}{l}\text { Log likelihood } \\
\text { No of observations }\end{array}$ & $-30.77 \mathrm{E}-07 * *$ & $4.0 \mathrm{E}-07$ & & \\
\hline$*$ Significant at 10\% & & & -56.295 & \\
** Significant at 5\% & & & & \\
$* * *$ Significant at 1\% & & & & \\
\end{tabular}

\section{Determinants of renting out land}

Table 4.6.summarizes the econometric evidence of renting out land and basically the results are inline with the theoretical expectations. However, out of the observed attributes, only three variables were statistically significant. Monthly income from agriculture showed significant negative relationships with both the choices, however, the impact on leases was fairly low. This can be accepted because efficient farmers who are generating higher incomes from agriculture will not tend to rent out their lands, in particular when the lands are under the control of state. Renting out behaviour shows a significant positive relationship with the extent of lands having titles, in both choices and with encroached lands and lands to which they have claims, the relationship was negative. Even though the land owners didn't have clear titles or rights to sell and transfer the lands, they were willingly to rent out land, when they had tenurial rights. In the case of some households the total extent under their control including the encroached and lands to which they had claims was far above the extent to which they had ownership rights. However, they were not willing to rent out such lands to which they did not have secure ownership rights and the negative sign of landlords having encroached lands further proves this. 
38

Table 4.6: $\quad$ Determinants of rented land out- Binomial logit estimates

\begin{tabular}{llclc}
\hline & \multicolumn{2}{c}{ Shared in } & \multicolumn{2}{c}{ Leased in } \\
& Coefficient & Std. Error & \multicolumn{1}{c}{ Coefficient } & Std. Error \\
\hline Constant & $\mathbf{- 1 . 6 7 2 1}$ & $\mathbf{0 . 4 4 3 6}$ & $\mathbf{- 2 . 9 6 6 9}$ & $\mathbf{0 . 7 3 3 4}$ \\
$\begin{array}{l}\text { Monthly income } \\
\text { from agriculture }\end{array}$ & $-1.8150^{* *}$ & 0.5324 & $-2.060 \mathrm{E}-04^{* *}$ & 0.0002 \\
$\begin{array}{l}\text { Total extent of land } \\
\text { with title }\end{array}$ & $0.3107^{* *}$ & 0.1585 & $0.3867 *$ & 0.2316 \\
$\begin{array}{l}\text { With encroached } \\
\text { land }\end{array}$ & $-1.6114^{* *}$ & 0.5735 & $-2.127^{* *}$ & 1.0875 \\
$\begin{array}{l}\text { Log likelihood } \\
\text { No of observations }\end{array}$ & -75.799 & & & \\
\hline * Significant at 10\% & & & -32.227 & \\
** Significant at 5\% & & & & \\
*** Significant at 1\% & & & & \\
\end{tabular}

\section{Impact of rental contracts on the socioeconomic status of the households}

Two linear regression models were fitted to analyse the impacts of the rental participation on the income and asset endowment of the tenants and the results are summarized in the tables 4.7. Since majority of the households are involved in diverse income earning activities separating out the absolute effect of the rental activities on the welfare of tenants is not easy. This supports the ladder hypothesis which implies that the rental involvement not only support to generate income but to savings and wealth accumulation as well. This clearly shows the possible positive implication of developing land rental markets in the State lands. Earlier studies carried out by the researcher (Marawila and Samaratunga, 2005) on the impact of rental transfers in agricultural lands of Sri Lanka, in general (including agricultural lands under both alienation programmes and private ownership), did not give such promising results.

Table 4.7: Impact of land extent on tenant's monthly income

\begin{tabular}{lccc}
\hline & Coefficient & Std. Error & Significance \\
\hline Constant & 3888.43 & 682.550 & 0.00 \\
Land extent with full & 1030.26 & 290.336 & $0.00^{* * *}$ \\
ownership rights & & & \\
Rented extent & 2057.35 & 264.093 & $0.00^{* * * *}$ \\
Asset endowment & 0.003 & 0.001 & $0.00^{* * *}$ \\
Adjusted R & $41.5 \%$ & & \\
DW statistics & 1.902 & & \\
\hline
\end{tabular}


Table 4.8: $\quad$ Impact of land extent on the asset endowment of tenants

\begin{tabular}{lccc}
\hline & Coefficient & Std. Error & Significance \\
\hline Constant & 197930.08 & 85667.06 & $.022^{* *}$ \\
Land extent with full & 167640.96 & 27117.58 & $0.00^{* * *}$ \\
ownership rights & & & \\
Rented extent & 85448.09 & 27867.58 & $0.002^{* * *}$ \\
With encroached land & -336759 & 85667.06 & $0.00^{* * *}$ \\
$\begin{array}{l}\text { Off farm income of } \\
\text { household }\end{array}$ & 20.773 & 6.764 & $0.002^{* * *}$ \\
Adjusted R & & & \\
DW statistics & $33 \%$ & & \\
\hline
\end{tabular}

\section{Conclusions and Policy Implications}

Land distribution programmes implemented, in particular during the post independent era, are mainly based on the ideology of preservation of the peasantry. Since then landlessness was considered a major cause of poverty and helping the poor to gain access to land was treated the major pro-poor strategy. Validity of this thinking even extends to the present days, as prevalence of poverty is dominant in the agrarian societies where the major form of wealth and source of livelihood is land. However, these state initiated programmes were not able to generate the expected benefit in the long run as other important issues affecting the livelihoods of allottees were not timely addressed. Problems related to infrastructure, landlessness among the successive generations and rigid regulations on the use and allocation of lands were observed as major limitations to farming in these areas. Resource immobility in particular land resource immobility due to inflexible regulations seems preventing the land transfers and effective use of land, reducing the overall contribution to the agricultural productivity. Similarly landlessness has prevented the efficient use of land further leading to conflicts within the community.

Restrictions on land sales can be understood and accepted on the grounds of possible adverse impacts on the poor. Conferring full ownership rights to the alienated State lands is likely to have a negative impact on the poor owing to the possibility of distress sales and lack of adequate safety nets to protect the poor from loosing lands and becoming poorer. However, restrictions on land rentals can hardly be accepted since they don't seem to be having positive contributions towards the wellbeing of the peasants. Instead they had led to social unrest and conflicts among the farming communities or even within own families since there were no proper follow up programmes of land distribution or any other alternative strategies to address the underlying problems. Relaxing the restrictions on rentals will provide the opportunity for tenants to engage more in long term contracts which are assumed to be secure and more advantageous to tenants compared to the short 
term share contracts. Transferring ownership rights though an unwieldy task; transferring user rights to land is likely to increase both the allocative and land use efficiency.

\section{References}

Alailima, P.J. (2001). Sri Lanka: Growth, distribution and redistribution. Ministry of Financing and Planning, Colombo.

Alwis, J. and R.D. Wanigaratne (2001). Agrarian reforms and agricultural productivity: A status review of Sri Lanka's experience. Report of the Asian Productivity Organization Meeting.

Balassuriya, T. S. and M. Maude eds., (1991), Land and Land use in Sri Lanka: Introduction. In: LOGOS, Vol. 29 Nos. 3\&4, Centre for Society and religion, Colombo.

Census of Agriculture (2002) <www.statistics.gov.lk/agriculture/AGC2002/ AGC2002.htm> .

Deninger, K. (2003). Land Policies for Growth and Poverty Reduction. World Bank: Washington DC.

Deninger, K. and G. Feder (2001) Agricultural Production. Hand Book of Agricultural Economics, $1 \mathrm{~A}: 289-325$.

Deininger K.and S. Jin (2005) The Potential of Land Rental Markets in the Process of Economic Development: Evidence from China. Journal of Development Economics, 78(1): 241-270.

Deninger, K., S. Jin, A. Berhanu, G. Samuel and D. Mulat (2003), Market and Non-market transfers of Land in Ethiopia; Implications for Efficiency, Equity and Non-farm development. Policy Research Working Paper 2992. World Bank: Washington DC.

Dharmaratne, D., A. Gunawardane, T. D. Marawila, R. M. Ranaweera Banda, P. Steele and C. Weerakkody (2006). Poverty and Social Impact Analysis (PSIA) of Sri Lanka's Land Reform. Institute of Policy Studies of Sri Lanka.

Fernando S. (2004), Land and water in Sri Lanka: To whom they belong? Law and Society Trust, 14: 201. 
Fernando, S. (2006). Land Research Action Network. [cited on 27 July, 2006].<http://landaction.org >

Gamage, D. (2000). Little space for maneuvering: Agrarian structure, land tenure regimes and agrarian development in Sri Lanka. Sri Lanka Agriculture for the Next Decade: Challenges and Opportunities, HARTI, Colombo.

Goonewardene, L.K.P. and C.J. Hatten (1990) Rationalizing land use, Economic Review, 15(10).

Institute of Policy Studies (2004). Land policy in Sri Lanka, Sri Lanka State of the Economy.

Madduma Bandara, C.M. (1990). Land use policy. Economic Review, 15(10).

Marawila, T. D. and P.A. Samaratunga (2005). Is land rental market of Sri Lanka helping the Poor? In, D. Melis, M. Abesuriya and N. de Silva (eds.), Putting Land First? Exploring the links between Land and Poverty, Centre for Poverty Analysis, Sri Lanka.

Marawila, T. D. and P.A. Samaratunga (2006). Role of land rental market in agricultural development in Sri Lanka. Economic Review, 32(1-5), April-August.

Mearns, R. (1999). Access to land in rural India. Policy Research Working Paper 2123, World Bank: Washington DC.

Rathnayake, R.M.K. (2002). Country case studies: Sri Lanka for poverty reduction strategy, Sri Lanka: Ministry of Finance Publication.

Samaratunga P.A. and T.D. Marawila (2006). Rural land sector in Sri Lanka: Major characteristics, determinants and implications for land policy. Institute of Policy Studies of Sri Lanka.

Silva, S.D. (2000). Skills, partnership and tenancy in Sri Lanka rice farms. Center Discussion Paper No. 819, Economic Growth Center, Yale University.

Sri Lanka Integrated Survey (SLIS) (1999-2000). Department of Census and Statistics, Sri Lanka.

Wanigaratne R. D. (2006). A Tentative Exploration of Links between Land and Poverty through a Rights-based Approach. In Putting Land First? 
Exploring the links between Land and Poverty. D. Melis, M. Abesuriya and N. de Silva (eds.). Centre for Poverty Analysis, Sri Lanka.

World Bank (2001). Project Appraisal Document for the Sri Lanka Land Titling and Related Services Project, World Bank Rural Development Sector Unit.

World Bank (1996). Sri Lanka: Non Plantation Crop Sector Policy Alternatives. Report No. 14563 CE. Washington DC.

Appendix 1: District details

\begin{tabular}{lll}
\hline \multicolumn{1}{c}{ District } & $\begin{array}{c}\text { Divisional Secretary's } \\
\text { Division }\end{array}$ & Gram Sevaka Division \\
\hline Kurunegala & Galgamuwa & Mahagalkadawala 82 \\
& Polpithigama & Dagama 370 \\
Anuradhapura & Kebithigollawa & Kanugahawewa 28 \\
& Kekirawa & Kumbukwewa 635 \\
Polonnaruwa & Alahera & Atharagallewa 2 \\
& Thamankaduwa & Palugasdamana 2 Ela 174 \\
Ampara & Adalachchanei & Deegawapiya 1 \\
& Maha Oya & Tampitiya 145 \\
& & \\
\hline
\end{tabular}

